\title{
"Honour" killings in Europe as an effect of migration process - perspective for Poland
}

\author{
Katarzyna Sadowa \\ UI. Mlodziezowa 33, 54-020 Wroclaw, Poland \\ E-mail address: katarzyna.sadowa@prawo.uni.wroc.pl
}

\begin{abstract}
Keywords: „honour” killings, European Muslim's minority, women's rights, violence, strategy for Poland
\end{abstract}

\begin{abstract}
In this paper the author analyses the phenomenon of so-called honour killings as an actual problem of European countries. The author shows that the issue is present in Europe as the result of immigration process and simultaneity is far from resolving. Moreover, while there is a great risk of its' increase, the proper combating measures are needed. As the author comes from Poland, the main aim of the publication is to stress that the problem of "honour" killings and wider "honour" based violence is a growing threat to this country. Therefore, adequate strategy preventing the issue should be prepare now.

Firstly, the author shortly characterizes the issue by providing proper definition and demonstrates its scale. The of the actual problem of "honour" killings in Europe is described especially by analysing the causal link between the immigration process and honour based violence. The second part of the publication contains the analysis of United Kingdom's strategy for fighting against "honour" based acts and its evaluation as an example of well-developed preventing measures. Finally, the author examines the recent Polish cases of "honour" killings and shows the risk of their growing impact on Polish society and law that justifies taking immediate steps (creating adequate strategy) to deter the increase of the problem.
\end{abstract}

\section{INTRODUCTION}

The phenomenon of so called honour killings is not new - the first cases occurred in preIslamic Arabia, yet unfortunately, it is still very actual in the worldwide perspective. Despite the fact that "honour" killings became a subject of international research mostly in the early 1990s, no universal definition of the phenomenon has been formulated. At the same time there were many different proposals of such definition in the literature. As an example, the definition constructed by Sara Hossain and Lynn Welchman, specialists on the research about "honour" killings, cited in the Report of European Committee on Equal Opportunities for Women and Men is: "Crimes of 'honour' are seen to encompass a variety of manifestations of violence against women, including 'honour killings', assault, confinement or imprisonment, and interference with choice in marriage, where the publicly articulated 'justification' is attributed to a social order claimed to require the preservation of a concept of 'honour' vested in male (family and/or conjugal) control over women and specifically women's sexual conduct, actual suspected or potential"[1]. This extended definition shows that the issue of "honour" killings is undoubtedly complex, which results in various scientific approaches, for instance, categorizing the issue as a domestic violence or as an example of wider phenomenon - violence against women (as women are victims of nearly $90 \%$ of all killings motivated by honour). However, there are also opinions, that such thing as "honour" killings do not even exist. As the first two approaches are justifiable, the latter denying the sense to distinguish "honour" killings from other forms of violence seems to be unacceptable. It is because there are some strong characteristic features of "honour" crimes, presented e.g. by P. Sen: "1.Gender relations that problematise and control women's behaviours, shaping and controlling women's sexuality in particular; 2. the role of women in policing and monitoring women's behaviour;3. collective decisions regarding punishment, or in upholding the actions considered appropriate, for transgressions of these boundaries; 4. the potential for women's participation in 
killings; 5. the ability to reclaim honour through enforced compliance or killings; 6 . state sanction of such killings through recognition of honour as motivation and mitigation".[2] The appropriate understanding of the "honour" killings' issue is conditional on considering the specific meaning of "honour". In short, in the context of "honour" killings (and wider - "honour" based violence) the idea of "honour" is strongly affected by gender: women are responsible (by means of their appearance, behaviour etc.) to ensure that men's or even wider - collective (family/community) honour will be preserved (in Muslim world such honour is called namoos/namus). Therefore, if woman acts in a way non-acceptable for man (or family), she is perceived to bring him (them) shame and the only way to eradicate "dishonour" is to punish her. In extreme cases such reaction may end with the woman's death. There is no catalogue of well-defined acts considered as "shameful", but most common examples may be indicated: adultery, rejection of a forced/arranged marriage, being in relationship non-approved by family, seeking divorce, use of alcohol and drugs, inappropriate clothing, homosexuality, running away from home, being a victim of rape/sexual abuse or sometimes even just a rumour about rendering one of these acts. The abovementioned characteristics proves that the phenomenon of "honour" killing should be undoubtedly distinguished as a specific type of crime.

\section{2. “HONOUR” KILLINGS AS A WORLDWIDE PHENOMENON}

"Honour " killings are considered to be characteristic mainly to Muslim countries. For example, as statistics say, annually in Pakistan even about 1000 women might be killed as a result of crimes motivated by "honour".[3] In Afghanistan 214 cases of women's deaths resulting from "honour" crimes were registered between March 2011 and March 2014 (however the real scale of the problem may be even five times higher).[4] Turkey also faces the problem of honour based violence, which is followed by at least 200 female victims per year.[5] However one of the highest number of these cases is noticed in India, where Hindus are still majority while Muslims are second population. Even about 1000 women annually are killed there because of their breach of "honour rules".[6] It must be highlighted that "honour" killings, being part of the wider phenomenon of honour based violence, are connected to culture but not to any specific religion - perpetrators of such crimes are Muslim, Hindus and Christians.[7] At this moment a popular thesis is presented in media, that the phenomenon of "honour" killings is strictly connected to Islam. Some of the specialists stress that the reason of such view is caused by "Islamophobia", which has been growing since the terrorist attack on the World Trade Centre on $11^{\text {th }}$ September 2001. Yet, according to different data, most of "honour" killings are committed by Muslims (e.g. nearly all "honour" killings in Great Britain have been carried out by Muslims from Pakistan and Bangladesh. Hindus and Sikhs are also perpetrators but much more rarely; research conducted by $\mathrm{P}$. Chesler indicates that for 172 "honour" killings' cases, 91\% worldwide were committed by Muslims, including 96\% of the killings committed in Europe and $84 \%$ of cases occure North America).[8,9] It should be clearly stated that there is no single mention of "honour" killing - neither prohibition, nor permission- in the main sources of Islam which are Koran and sunna. As the result, there is no direct connection between phenomenon of "honour" killings and religion of Islam, however such association exist in connection with (addition to) Muslim culture in the broad sense. Simultaneously the boundary between 'culture' and 'religion' regarding Islam is hard to establish.

\section{3. "HONOUR" KILLINGS IN EUROPE}

The great number of "honour" killings cases in some of the abovementioned countries is undoubtedly very disquieting in the perspective of 21 st century and human rights development. It seems to be an evidence of ineffectiveness and lack of legal and practical measures that should guarantee the safety and protection of basic human rights. But even more disturbing is the fact that the phenomenon of "honour" killings has expanded during last 20-30 years in Europe, which has been highlighted e.g. in the already mentioned Report of European Committee on Equal 
Opportunities for Women and Men: "In Western countries, there used to be a tendency to believe that so-called honour crimes occurred exclusively in certain Asian countries, such as Pakistan, Afghanistan and Bangladesh, some African countries and the Middle East. However, over the last twenty years, there is no denying that so-called honour crimes have become increasingly common in Europe, particularly in France, Sweden, the Netherlands, Germany, the United Kingdom, and Turkey".[10] As statistics say, during the last dozen years in selected countries the number of socalled honour killings annually amounted to about 10-12 in Great Britain, 12 in Germany, 11-14 in Netherlands and 5 in Belgium.[11] Simultaneously, many researchers emphasize that due to common tendency to cover up such acts and/or make them look like accidents/suicides and because of the complexity of the issue these numbers may be much lower than the real scale. Some statistics regarding United Kingdom may be shown as an example: between April and October 2009 police recorded 211 "honour" based acts in London.[12] As commander S. Allen claims in N. Khanum's report there are about 500 "honour" based cases reported to the police and Forced Marriage Unit annually in Oxford. The commander "described HBV [honour based violence] as 'massively' under-reported and suggested that if this was multiplied by 35, representing the number of experiences the average victim of DV [domestic violence] suffers before reporting, 'you may be somewhere near where people's experience is, but we simply don't know.' This would suggest 17,000 cases"'[13]. Such opinion is not surprising, because the worldwide scale of "honour" killings is greatly underestimated. To give an example of expert opinion by Diana Nammi, director of Iranian Kurdish Women's Rights Organisation (IKWRO) who asserts that the real number of "honour" killings reaches at least 20000 (the official number is 5000).

Coming back to the Muslim culture reference of "honour" based violence, in the European countries facing the growth of phenomenon, there are notable amounts of Muslim minorities. According to the Pew Research' Report the percentage of Muslim in selected European countries in 2010 amounted to: Belgium 6\%, France 7,5\%, Germany 5,0\%, Netherlands 5,5\% Sweden 4,9\%, United Kingdom 4,6\%. The increase of those number until 2030 is projected as follows: Belgium 10,2\%, France 10,3\%, Germany 7,1\%, Netherlands 7,8\% Sweden 9,9\%, United Kingdom 8,2\%, however basing on actual data, these numbers may be even higher.[14] Due to the fact that the highest numbers of "honour" crimes occur in European countries where percentage of Muslim minority is significant, the thesis that emergence of the phenomenon in Europe results from migration process seems to be correct. Similarly, the expected growth of Muslim's minorities in the West might increase the "honour" crimes phenomenon in upcoming years. Many researchers emphasize, that the problem is far from resolving and it is not a temporary issue regarding only the first generation of immigrants, but rather an indigenous and self-perpetuating one that is carried out by present (third or fourth) immigrants' generation.

Taking into consideration all these facts suggesting that the phenomenon of "honour" killings is (unfortunately) actual and growing, the effective strategies to eradicate the problem are needed. Proper knowledge and understanding of the issue by official agencies responsible for fighting with violence is crucial.

\section{THE BRITISH STRATEGY FOR COMBATING HONOUR BASED VIOLENCE}

The following part of this publication presents an analysis of dangers arising from the development of this phenomenon in Poland, accompanied by the case-study, as well as the measures that are need to be applied to appropriately combat the negative effects of the issue. For this purpose, a short examination of the programs designed to fight "honour" based violence that have been engaged in United Kingdom serves as a starting point to discussion and an example of well organised development of such measures in the country which is strongly affected by the issue.

In United Kingdom, the country where the percentage of Muslim-origin immigrants is quite significant, the model of multicultural society had been functioning impeccably for a long time. The scepticism regarding this approach started emerging in 2001, when some serious race riots between Asian and white communities occurred United Kingdom. The crisis of existing immigrant policy 
arose as a result of terrorist attack in USA on $11^{\text {th }}$ September 2001. Four years later, British multicultural model de facto collapsed, as the bombing attack on metro in London was carried out by individuals of foreign origin born or brought up in Great Britain. A lot of queries pertaining the failure of immigrants' assimilation and integration were raised questioning the effectiveness of British model.[15] Simultaneously, a discourse regarding "honour" killings started to develop considerably, even though the problem had been debated de facto since 1997 through the activity of New Labour interested in analysis of controversial violent practices against women committed by minorities.[16] The phenomenon of "honour" killings was recognised with connection to the issue of arranged/forced marriages (which were fought most effectively). Initial approach to perceive "honour" killings as a culture affected problem had prevailed, but soon after as the discourse concerning the issue developed, some serious objections regarding the efficiency of such classification appeared (mainly due to women's organisations' activity). Some specialists emphasized that women affected by "honour" based violence, belonging mainly to minorities, are left without any official help due to cultural approach. That was because of increasing ineffectiveness of multicultural model and fear of being accused of political incorrectness or being "Islamophobic". All this underscores an existence of double risk in perceiving "honour" based violence as a typical "cultural" phenomenon: firstly, in criminal cases perpetrators may raise an argument of "cultural defence" trying to mitigate the sentence; [17] secondly, "many young women from ethnic minority communities are at risk of not being fully protected by the state as equal citizens as they are invisible. Within the discourse of multiculturalism, women 'fall between the cracks'. In this discourse 'race' and ethnicity is prioritised and gender differences and inequalities are rendered invisible. However the killing of women must never been seen as cultural matter, but always as a human rights issue"[18]. The above defects in "cultural" approach resulted in new strong voices in British public discourse calling to recognize "honour" killing as a human rights violation - or more specifically - as a violence against women or domestic abuse, taking into account its specific features of "honour" based violence. This change in perspective was initiated by women's organisations, such as Southall Black Sisters, Karma Nirvana, Iranian Kurdish Women's Rights Organisation (IKWRO), Equality Now and others.[19,20,21,22] According to S.A. Ercan, due to such organisations three crucial modifications regarding British approach to fight against "honour" killings were implemented: "First they have claimed that the state should recognise that domestic violence is not a gender-neutral phenomenon. It is perpetrated mostly by men against women and should be define within the broader context of VAW [violence against women] (...) Second, (...)in order to specificity of 'honour killings', the perpetrators of domestic violence should not be restricted to partners and ex-partners but should include wider family members, such as uncles and brothers. Third, women's movement actors have demanded changes in murder laws to prevent the courts from accepting cultural reasons as a mitigating factor".[23] However, despite successful inclusion to the public discourse domestic violence and violence against women aspect of "honour" killings, the cultural factor was not entirely abandoned. Ercan pointed, that this new approach may be seen as a R. Reddy's "mainstreaming plus" approach that combines the necessity both to treat "honour killings" as an element of gender based violence and to provide for some specifics of cultural motivation.[24] Nevertheless, the adequate, balanced consideration of cultural factor in "honour" killings' cases remains troublesome, as Reddy claims: "it seems that the law often continues to identify such cases primarily according to cultural criteria. However, elsewhere the law has taken a contradictory position and ignored cultural context, which can also result in injustice to victims of gender violence(...) At the same time, greater focus on the gendered aspects of honour-related violence would place it more firmly within the spectrum of violence against women across all communities in the UK, with less risk of stereotyping and stigmatising ethnic minority communities.(..) it is to be hoped that the need to incorporate both gender and cultural factors appropriately into the legal process will become more evident".[25] It is worth to notice that official strategy implemented by Association of Chief Police Officers (ACPO) in 2008 visibly promoted gender based violence approach. The strategy included official definition of "honour" based violence which has been constructed in general way as "a crime or incident, which has or 
may have been committed to protect or defend the honour of the family and/or community"'[26]. Notably, despite that the British strategy regarding the combat against "honour" killings is still evolving, some official measures were implemented. The significant role in eradicating the phenomenon is played by non-governmental women's organisations, but at the same time special police units are trained to appropriately and effectively react to the potential "honour" based violence cases. Implementation of adequate strategy and creation of effective approach is undoubtedly crucial to the safety of women exposed to the risk of being the victim of honour based violence. Undoubtedly, the lack of such mechanisms may have had tragic effects, as for example in well-known case of Banaz Mahmod's murder in 2006 (despite allegations about assaults, threats and the risk of life reported to the police by victim several times, she was brutally killed by her family's members; the mistakes committed by police played important role in this tragic scenario of the case).[27] The history of the British strategy, its failures and successes and the negative effects resulting from the lack of appropriate protective measures should be a good lesson for Poland, which starts to face the phenomenon in its territory.

\section{THE RISK OF "HONOUR" KILLING'S INCREASE IN POLAND}

It may now seem that Poland is safe from the problem of "honour" killings, as being the country with relatively low amount of minorities living there. The last Population and Housing Census from 2011 showed that only $1,55 \%$ of people registered declared non-Polish nationality and 2,26\% declared both foreign and Polish nationality.[28] Yet simultaneously, as the official data says, Muslim population in Poland is growing. According to Polish Central Statistics Office, the number of Muslim League members in 2006 in Poland was 208 and increased to 3800 members in 2010. The number of Muslim Religious Association in Poland's members increased from 1061 in year 2010 to 1332 in year 2012 and according to data revealed in 2014 Statistical Annual - the number of shia movement Ahl-u Bayat is now 5000.[29] In big cities such as Warsaw, Wroclaw or Krakow, the raise of the Muslim culture's representatives is getting considerably more visible (i.e. through the increased number of women wearing traditional Muslim scarfs or even burkas and nikabs). The number of immigrants coming from the countries where "honour" culture is common will probably rise also as a result of taking thousands of refugees from these countries in oncoming years (so far the Government has declared to accommodate two thousands Syrian refugees).[30] Therefore, considering the before mentioned data showing that so far the main perpetrators of "honour" killings in the worldwide perspective were the representatives of Muslim culture, during following years the problem of "honour" based violence may increase also in Poland. Analyzing the evolving, long-lasting process of adopting the effective preventive measures against this phenomenon on the example of United Kingdom, one might assert that adequate actions to prevent such cases of "honour" based violence happening in Poland should start being created now. Above assumptions seem to be true especially in the light of the recent two cases having features characteristic for "honour" killings that occurred in Poland.

First one is the murder of Agnieszka Fojtuch by Naeem Abbas. In 1997 she met Naeem in Łodz shortly after coming back from Pakistan - they got married and had three kids. The situation radically changed when the whole family moved to Pakistan in 2004. Agnieszka was humiliated by her husband and his family. One year later she managed to come back to Poland, but the children stayed in Pakistan. She was in tragic financial situation and was forced into prostitution to earn thousands of zlotys that Naeem demanded from her to "buy out" back her children. Regardless the payment, Naeem was still refusing to give back children and, as a result, Agnieszka went to Pakistan, from where she eventually managed to run away with her children to Poland in 2008. Nevertheless, her nightmare did not end and on 7th June 2009 she went missing. On 10th June Police that searched for her found her dead nearby some road. According to the investigation, Agnieszka Fojtuch was killed by her husband Naeem by getting numerous stab wounds; the murder was undoubtedly planned. The perpetrator (who did not admit his guilt) was sentenced to fifteen years of imprisonment (the maximum penalty for murder in Poland is life sentence). The 
investigation was classified "for the good of the children", so only available information are from public media.[31]

The second case was the murder committed in November 2014 in Grudziadz. As the case is relatively new, even less facts are accessible so far. Nevertheless, as media report, the victim Kamila - met Fehmin B. in 2009 online on the portal for disabled. They fell in love and in 2010 Fehmin (an Albanian coming from Kosovo) came to Poland. Soon after Kamila gave birth to their son, their peaceful life ended quickly. In 2012 Kamila told her parents that Fehim had been using psychological and physical violence against her and even threatened her once with the knife. The man was taken to the shelter; he claimed that their relationship had fallen apart because of his problem with finding job and because of Kamila's permanent criticism. He decided to go to Wieden and then back to Kosovo. Nevertheless he was sending threats to Kamila at that whole time that he would come back and kill her because of her disobedience to him - "I will come to Poland and I will kill you(..) I told you many times that I will kill you, but you did not belive me. I will put the knife in your heart. Allah told me to kill you, I have His approval! Even if I will go to jail ". [32] In November 2014 Kamila was found almost dead on the street near garages with a lot of wounds. Before dying on November $15^{\text {th }}$ she was able to give testimony that she had been attacked with knife by Fahim. The man had left the crime scene but was stopped by the police in Krakow on November 12 and was accused of murder - the proceedings are pending.[33]

Even though both abovementioned cases have characteristics of "honour" crimes - both were committed as an act of revenge by furious men feeling somehow "dishonoured" by their victims, both were also planned. There is no official reasons for why the sentence in first case was only 15 years; there is possibility that the judge referred to the "cultural defence". Sentence in Fehmin's case will be announced probably during oncoming months.

Unfortunately, there are no special legal mechanisms with regards to "honour" based violence cases in Poland so far. Simultaneously, as my preliminary researches shows, there is also no uniform stance in the environment of attorneys and judges regarding this problem: some of them, asked if they will refer in such cases to "cultural defence", were convinced that this is a proper way to judge over perpetrators whose motives to commit the crime were affected by culture. There is also group of lawyers, who are of the different view that the cultural motivation should not be used as a mitigation factor. Due to the fact that there is a risk that the number of "honour" crimes in Poland will increase within oncoming years, there should be created a unified strategy to effectively combat such acts. Learning from the mistakes made by other countries, the Polish Government should be prepared before the scale of the issue will develop. Some initial steps should be taken now, as, based on the research of the development of the protective measures applied in United Kingdom, it is easy to see that this is a complex and long-term process. Police staff and employers of other social agencies should be trained to properly recognize and react on cases of "honour" based violence. The specific features of the phenomenon (especially careful planning and involvement of other family members) need to be known by police officers working with the cases of domestic abuse or violence against women. The lack of proper knowledge regarding "honour" based violence may undoubtedly lead to a tragic end (the abovementioned case of Banaz is the best, sad example of this).

Having been analysing the phenomenon of "honour" killings for a few years, I am personally in favour of treating them as a type of violence against women and domestic violence (as it is now in United Kingdom). Considering that almost all of the victims are women, gender distinguished approach should be included. Moreover, I am of the opinion that the possibility of using the "cultural defence" by the perpetrators to seek the mitigation of the court sentences should be definitely excluded - they should be judged as common murderers. By allowing "cultural defence" we decide to place values of other cultures above basic values of our culture, such as a right to life or equality. The researches carried out by me and my colleagues from Centre for Oriental Law Research[34] under the direction of professor Miroslaw Sadowski are intended to give an impulse for Polish lawyers, government and non-governmental organizations to start developing strategy and measures for the prevention and fighting against "honour" based violence. 


\section{CONCLUSIONS}

In conclusion, indisputably the problem of "honour" killings and other forms of "honour" based violence is still actual and far from resolving. At the same time, as a result of immigration process, the issue became characteristic not only for Middle East and Asian countries but also for Europe. Many western European countries, such as United Kingdom, Sweden, Netherlands or Germany are facing with the problem so far and develop different strategies and approaches which are evolving all the time. Nevertheless new cases of "honour" based violence are still being exposed. By analysis of statistics, predictions and above mentioned cases I am sure that the phenomenon will evolve also in Poland, especially because of immigration' process and accommodation of thousands of refugees from countries where "honour" culture is common.

\section{References:}

[1] Report of European Committee on Equal Opportunities for Women and Men, The urgent need to combat so-called "honour crimes", ( Doc. 11943 | 08 June 2009).

[2] P. Sen, 'Crimes of honour' value and meaning, in: L. Welchman, S. Hossain, 'Honour'. Crimes, paradigms, and violence against women, Zed Books, New York, 2005, pp. 42-63.

[3] Refugee Documentation Centre of Ireland, Pakistan, 31 January 2011, available on: http://www.refworld.org/pdfid/4d54e3d42.pdf

[4] M. Hussain Sarmand, L. Sultani, The Report of AIHRC, Violence against women in Afghanistan. (The first six months of the year - 1392), available on: http://www.aihrc.org.af/home/research_report/2091

[5] A Report to the Committee against Torture, Violence against Women in Turkey, May 2003 (CAT/C/20/Add.8); http://hbv-awareness.com/turkey-grapples-with-spike-in-honor-killings/

[6] Information on: http://hbv-awareness.com/;

http://www.aljazeera.com/indepth/opinion/2013/11/honour-killings-india-crying-shame20131127105910392176.html; http://in.reuters.com/article/2012/04/02/india-womenhonour-killing-idINDEE8310GP20120402.

[7] A.C. Kortweg, G. Yurdakul, Religion, Culture and the Politiczation of Honour-Related Violence. A Critical Analysis of Media and Policy Debates in Western Europe and North America, Gender and Development Programme Paper Number 12, United Nations Research Institute for Social Development, Geneva, 2010.

[8] J. Brandon, S. Hafez, Crimes of the Community. Honour-based violence in the UK, The Cromwell Press, Trowbridge 2008, p. 39.

[9] Information on: http://www.meforum.org/2646/worldwide-trends-in-honor-killings

[10] Report of European Committee on Equal Opportunities for Women and Men, The urgent need to combat so-called "honour crimes", ( Doc. 11943 | 08 June 2009).

[11] SURGIR, Combating honour crimes In Europe, edition 2011-2012; S. Hafez, Crimes of the Community. Honour-based violence in the UK, The Cromwell Press, Trowbridge 2008; D. Oberwittler, J. Kassel, Honour Killings in Germany. A Study based on prosecution files, Wolters Kluwer Deutchland, Koln, 2011.

[12] Information on: http://ikwro.org.uk/wp-content/uploads/2012/03/Briefing-on-HBV-and-theViolence-Against-Women-and-Girls-Action-Plan-March-2011.pdf

[13] N. Khanum, Forced Marriage and Honour Based Violence in Oxford. Key Findings and Areas for Improvement (Summary version of main report), Oxford, 2009.

[14] Information on: http://www.pewforum.org/files/2011/01/FutureGlobalMuslimPopulationWebPDF-Feb10.pdf

[15] T. Modood, Remaking multiculturalism after 7/7, Open Democracy, 2005.

[16] M. Dustin, M. Phillips, Whose Agenda Is It?, Ethnicities 8(3) (2008), pp. 405-424. 
[17] V. Mateo, H.S.Mirza, „There is nothing 'honourable' about honour killings”: gender, violence and the limits of multiculturalism, 2006; information on: http://eprints.ioe.ac.uk/2018/1/meetooandmirza2007nothinghonourable187.pdf

[18] S. Salim, It's about women's rights and women's rights are human rights - an interview with Sawsan Salim, Coordinator of Kurdistan Refugee Women's Organisation received at Stop Violence Against Women Honour Killing Conference 28 October 2005, London, in: V. Mateo, H.S.Mirza, „There is nothing 'honourable' about honour killings”: gender, violence and the limits of multiculturalism, 2006.

[19] Information on: http://www.southallblacksisters.org.uk/

[20] Information on: http://www.karmanirvana.org.uk/

[21] Information on: http://ikwro.org.uk/

[22] Information on: http://www.equalitynow.org/

[23] S.A. Ecran, Same Probem, Different Solutions: The Case of 'Honour Killings' In Germany and Britain, in: A.K. Gill, C. Strange, K. Roberts, 'Honour' Killing \& Violence, Theory, Policy \& Practice, Palgrave Macmillan, New York, 2014, pp.199-217.

[24] R. Reddy, Approaches to Honour-Related Violence in the English Legal System', PhD Thesis, London 2010 p.260, in: A.K. Gill, C. Strange, K. Roberts, 'Honour' Killing \& Violence, Theory, Policy \& Practice, Palgrave Macmillan, New York, 2014, p.208.

[25] R. Reddy, Gender, Culture and the Law: Approaches to 'Honour Crimes' in the UK, Springer Science+Business Media B.V., London 2008.

[26] Association of Chief Police Officer of England, Wales \& Northern Ireland, Honour Based Violence Strategy, London, 30 September 2010.

[27] Independent Police Complaints Commission, Independent Investigation-Executive Summary, Contact between Banaz Mahmod and the Metropolitan Police Service and West Midlands Police Setember 2005-January 2006, November 2008, available on: https://www.ipcc.gov.uk/sites/default/files/Documents/investigation_commissioner_reports/ banaz_mahmod_executive_summary_nov_08_v7.pdf; J. Brandon, S. Hafez, Crimes of the Community. Honour-based violence in the UK, The Cromwell Press, Trowbridge 2008, pp. 59-60, 114-115; I recommend also to see a movie: Banaz a Love Story, directed by Deeyah Khan, United Kingdom/Norway, Fuse Film, 2012.

[28] Information on: http://stat.gov.pl/spisy-powszechne/nsp-2011/nsp-2011-wyniki/ludnoscstan-i-struktura-demograficzno-spoleczna-nsp-2011,16,1.html\#

[29] GUS, Wyznania religijne, Stowarzyszenia narodowościowe i etniczne w Polsce 2009-2011 Warszawa 2013, pp. 121-125; GUS, Rocznik Statystyczny Rzeczypospolitej Polskiej 2014, Warszawa 2014.

[30] Information on: https://www.msw.gov.pl/pl/aktualnosci/13526,Polska-podtrzymaladeklaracje-przyjecia-2-tys-uchodzcow.html

[31] Infromation on:

http://wyborcza.pl/duzyformat/1,137626,15731376,Troche_potegi_Zabojstwo_honorowe_ w_Polsce.html; www.euroislam.pl/index.php/2011/01/honorowe-morderstwa-dotarly-dopolski/; http://www.euroislam.pl/index.php/2012/03/honorowe-morderstwo-w-polsce/

[32] http://www.pomorska.pl/apps/pbcs.dll/article?AID=/20150710/GRUDZIADZ01/150709150

[33] Information on:

http://www.pomorska.pl/apps/pbcs.dll/article?AID=/20150710/GRUDZIADZ01/150709150; http://www.se.pl/wiadomosci/polska/grudziadz-muzumanin-zamordowa-zone-bo-nie-byaposuszna_644942.html

[34] Information on: http://prawaorientu.prawo.uni.wroc.pl/eng/ 